\title{
14
}

\section{Teknocentric kin terms in Australian languages}

\author{
Harold Koch
}

\section{Introduction and overview ${ }^{1}$}

Australian Indigenous languages have long been known to have systems of kinship terminology that are shared across much of the continent and differ widely from those of well-known European languages. ${ }^{2}$ For instance, they typically distinguish between elder and younger siblings, between a mother's and a father's child, between maternal and paternal 'uncles' and 'aunts' (MB vs FB and MZ vs FZ: see note 3 for clarification of abbreviations), between maternal and paternal grandparents (MM vs FM, MF vs FF). ${ }^{3}$ On the other hand, some relations are not distinguished terminologically; for example a parent and their same-sex siblings (so $F=F B$ and $M=M Z$ ); or siblings and parallel cousins (so FBS or $\mathrm{MZS}=\mathrm{B}$, etc.). Another characteristic of Australian kin terminologies is

1 It is with pleasure that I present this study in honour of my long-term colleague Anna Wierzbicka. I thank the editors and two reviewers for useful feedback.

2 Further discussion and exemplification of Australian kinship systems can be found in standard works on Australian anthropology, e.g. Elkin (1964) and Berndt and Berndt (1977).

3 For the description of kin relations I here use a version of the kind of abbreviations widely used in kinship studies; all kin relations are reduced to strings of these symbols. Kinship symbols used, following the practice of the AustKin project (see below), are: $\mathrm{B}=$ brother, $\mathrm{C}=$ child, $\mathrm{D}=$ daughter, $\mathrm{e}=$ elder, $\mathrm{f}=$ female's, $\mathrm{F}=$ father, $\mathrm{H}=$ husband, $\mathrm{m}=$ male's, $\mathrm{M}=$ mother, $\mathrm{S}=$ son, $\mathrm{Sb}=$ sibling, $\mathrm{Sp}=$ spouse, $\mathrm{W}=$ wife, $\mathrm{y}=$ younger, $\mathrm{Z}=$ sister. For a critique of this style of definition from the Natural Semantic Metalanguage (NSM) perspective see Wierzbicka (2013). See section 5.3 and note 24 for further comments relating the findings of this study to the NSM approach. 
the reciprocal use of some terms. ${ }^{4}$ The same term may denote a grandparent and grandchild: for example, $\mathrm{FF}=\mathrm{mSC}, \mathrm{MM}=\mathrm{fDC} .{ }^{5}$ Likewise for affinal (in-law) terms: for example, $\mathrm{WM}=\mathrm{fDH}, \mathrm{HB}=\mathrm{mBW}$. Abbreviations for the main kin relations discussed here are set out in Table 14.1, arranged according $\mathrm{C}$ (onsanguineal) vs $\mathrm{A}($ ffinal) relation and to generation $(\mathrm{G})$ relative to the propositus.

Table 14.1. Kin abbreviations.

\begin{tabular}{|l|l|l|l|l|}
\hline C G+2 & $\begin{array}{l}\text { MM mother's } \\
\text { mother }\end{array}$ & $\begin{array}{l}\text { MF mother's } \\
\text { father }\end{array}$ & $\begin{array}{l}\text { FM father's } \\
\text { mother }\end{array}$ & $\begin{array}{l}\text { FF father's } \\
\text { father }\end{array}$ \\
\hline C G-2 & $\begin{array}{l}\text { fDC female's } \\
\text { daughter's child }\end{array}$ & $\begin{array}{l}\text { mDC male's } \\
\text { daughter's child }\end{array}$ & $\begin{array}{l}\text { fSC female's } \\
\text { son's child }\end{array}$ & $\begin{array}{l}\text { mSC male's } \\
\text { son's child }\end{array}$ \\
\hline C G+1 & M mother & $\begin{array}{l}\text { MB mother's } \\
\text { brother }\end{array}$ & F father & $\begin{array}{l}\text { FZ father's } \\
\text { sister }\end{array}$ \\
\hline C G-1 & $\begin{array}{l}\text { fC female's } \\
\text { child }\end{array}$ & $\begin{array}{l}\text { mZC male's } \\
\text { sister's child }\end{array}$ & $\begin{array}{l}\text { fBC female's } \\
\text { brother's child }\end{array}$ & $\begin{array}{l}\text { mC male's } \\
\text { child }\end{array}$ \\
\hline C G0 & Z sister & $\begin{array}{l}\text { MBC mother's } \\
\text { brother's child }\end{array}$ & $\begin{array}{l}\text { FZC father's } \\
\text { sister's child }\end{array}$ & B brother \\
\hline A G0 & W wife & $\begin{array}{l}\text { WSb wife's } \\
\text { sibling }\end{array}$ & H husband & $\begin{array}{l}\text { HSb husband's } \\
\text { sibling }\end{array}$ \\
\hline A G+1 & $\begin{array}{l}\text { WM wife's } \\
\text { mother }\end{array}$ & $\begin{array}{l}\text { WF wife's } \\
\text { father }\end{array}$ & $\begin{array}{l}\text { HM husband's } \\
\text { mother }\end{array}$ & $\begin{array}{l}\text { HF husband's } \\
\text { father }\end{array}$ \\
\hline A G-1 & $\begin{array}{l}\text { fDH female's } \\
\text { daughter's } \\
\text { husband }\end{array}$ & $\begin{array}{l}\text { mDH male's } \\
\text { daughter's } \\
\text { husband }\end{array}$ & $\begin{array}{l}\text { fSW female's } \\
\text { son's wife }\end{array}$ & $\begin{array}{l}\text { mSW male's } \\
\text { son's wife }\end{array}$ \\
\hline
\end{tabular}

Source: Author's summary.

Two further characteristics of Australian kin terminology should be mentioned. First, kin terms may be extended beyond the immediate family. There are widely recurrent principles by which kin terms that describe genealogically close relations are extended to more distantly related relatives; these have been explored especially by Scheffler (1978). Second, affinal (in-law) relatives typically belong to particular classes of consanguineal relatives (depending on the marriage rules applying in each society); for example, a spouse is often a kind of cross-cousin (i.e. child of FZ or MB), WM a kind of FZ, WF a kind of MB, etc. There may

\footnotetext{
4 Cousin is a reciprocal term in English.

5 In some cases, the terms are not identical but are derivationally related: either the senior or the junior term may involve an affix added to the shared stem.
} 
be alternative ways of referring to someone depending on whether they are (potentially) related by marriage in addition to their (classificatory) consanguineal relation.

The subject of this chapter is a further kind of terminological relation that has come to light in connection with the compilation of kinship terminology for the AustKin project (see Dousset et al. 2010; www. austkin.net). A puzzling systematic formal relation exists between terms denoting one's spouse's parents (and reciprocally one's child's spouse) and grandkin terms. This was first noted in Dharumba data (from around Ulladulla, NSW), then observed in Ngarrindjeri from South Australia, and finally found, with more of an explanation, in languages of Cape York Peninsula. The respective data sets are discussed in sections 2, 3 and 4 respectively. This unavoidably involves some discussion of the morphology of the forms. Then in section 5, I provide an explanation in terms of pragmatics, the altercentric usage of consanguineal terms to denote affinal relatives, for which I propose the term 'teknocentric', and explore some of the implications of these results for semantic description, semantic change and the etymological study of Australian kin terms.

\section{Dharumba}

The Dharumba kinship data were collected as one of the 'schedules' prepared at the behest of Fison and Howitt. ${ }^{6}$ The Fison and Howitt schedule F.15, said to be from the Búrgural tribe in the Jervis Bay district, was recorded on 28 September 1874 by Andrew Mackenzie of Moelly, Wandandian (near Ulladulla). ${ }^{7}$ This is the same Andrew Mackenzie whose documentation of Dharumba (and Dharrawal) is analysed in Besold's (2012) study of historic documentation of the Yuin languages of the New South Wales South Coast. Mackenzie's kinship data are presented as a family tree with 22 named individuals, followed by 10 lists detailing the terms used by 10 of the individuals for the other persons on the table. This yields 44 kin terms, many of which have several senses. The use of the genealogical method of elicitation has yielded not only a greater

6 For Fison and Howitt's kinship studies, including the 'schedules' they solicited, see McConvell and Gardner (2016).

7 The manuscript containing the Australian kinship schedules is in the Lorimer Fison papers within the Tippett Collection in the library of St Marks National Theological Centre, Canberra. 
number of kin terms, ${ }^{8}$ but increased precision in the reference of terms usually translated as 'grandmother', 'father-in-law', etc. Mackenzie's data, however, also present us with a puzzle; the terms reveal an intriguing set of formal relations between grandkin terms and parent/child-in-law terms, which cries out for an explanation.

Table 14.2 sets out the relevant terms, with spellings normalised and rendered into a standard orthography. ${ }^{9}$ Note that the grandkin terms occur both with and without a final syllable -nga, whose significance is not known. For pawu(nga) the longer form occurs only with reference to the junior member (i.e. fDC). For kupa(nga), both the longer and the shorter forms occur in both senior and junior reference. For $k a(t y)$ panga (forms with and without ty occur) there is no short form. Ngapupu, which appears to be a partially reduplicated form of ngapu, occurs only as a senior term, and the corresponding junior term involves a suffix -ara, with elision of the stem-final $u$.

Table 14.2. Dharumba terms for grandkin and affines.

\begin{tabular}{|l|l|l|l|}
\hline Grandkin gloss & Grandkin form & Affine form & Affine gloss \\
\hline MM/fDC & pawu(nga) & pawiri & WM/fDH \\
\hline FF/mSC & kupa(nga) & kupanthiri & HF/mSW \\
\hline FM/fSC & ka(ty)panga & ka(ty)panthiri & $\mathrm{HM} / \mathrm{fSW}$ \\
\hline MF/mDC & ngapupu/ngapara & ngaparama & WF/mDH \\
\hline
\end{tabular}

Source: Adapted from Mackenzie (1874) [see note 7, this chapter].

Affinal terms for parent-in-law and child-in-law appear to be based on the stem of the grandkin terms - although there are irregularities. Thus pawiri involves -iri added to pawu, with vowel elision. Two other terms, $k a(t y)$ panthiri and kupanthiri, appear to contain a suffix -nthiri. The fourth affinal term, ngaparama, appears to suffix - ma to the junior grandkin term ngapara. Although the suffixes differ somewhat, there is a clear pattern of deriving terms for parent/child-in-law from terms for grandparent/grandchild. Specifically, the term for spouse's parent (and its reciprocal) is consistently related to that for the parent of one's own parent of the same sex as the spouse: compare WM with MM, WF with MF, HM with FM, and HF with FF. Why should this be so? Is a similar pattern found elsewhere?

8 The traditional stories he recorded yielded only eight kin terms.

9 It is impossible to know whether $r$ represents a tap/trill or an approximant; the two rhotics typically contrast in Australian languages. 


\section{Lower Murray languages}

\subsection{Ngarrindjeri}

The language spoken-up to the mid-twentieth century-by the Narrinyeri, now called Ngarrindjeri, around the mouth of the Murray River in South Australia was described in the nineteenth century by Meyer (1843) and Taplin (1873), reproduced in an appendix to Taplin (1879). I am here concerned with a subset of the kinship terms. Some of the kin terms are extraordinarily difficult to understand, due to a plethora of prefixes, suffixes and suppletive stems. The grandkin terms to be discussed, however, lack some of these complexities. The meanings are assured due to the fact that Taplin used Fison and Howitt's genealogical method of eliciting kin terms; that is, terms were gathered with reference to the relationship of individuals known to the informant. The same kin terms are also given in later works by Radcliffe-Brown (1918) and Berndt and Berndt (1993).

The grandkin terms are presented in Table 14.3. The citation forms for the grandparental terms include the marker of first person propositus, -ano(wi) 'my'. The base of the lexeme is given in the next column. (For MF the form marked for third person propositus, ngatyapali 'his/ her MF' is also known.) The junior reciprocal terms, female's daughter's child (fDCh) etc., are provided in column four. They are derived from the senior terms by means of a suffix -ari (or probably just -ar, since $-i$ is singular marker). Forms without the final $-i$ are found in Radcliffe-Brown (1918) and Berndt and Berndt (1993). These later sources also indicate junior forms without the suffix (i.e. pak, muth and ngaty), which suggests that the junior relatives need not be overtly marked with the junior suffix; that is, the unsuffixed forms have as their referent either a grandparent or the reciprocal grandchild. As in many Australian kin systems, these grandparental terms extend to the siblings of each grandparent; thus pakanowi MM can also refer to MMZ or MMB. The same extension applies to junior terms; thus pakari can refer not only to daughter's child of a woman but also to the daughter's children of the sister or brother of the grandmother. The same suffix - ar(i) that indicates the junior member of a grandkin relation is found with some other kin terms as well. Thus the reciprocal of FZ ngampano(wi), which has a short form $(m)$ pano, is (nga)mpari, and the reciprocal of $\mathrm{FeB}$ ngopano(wi) is ngopari. 
Table 14.3. Grandkin terms.

\begin{tabular}{|l|l|l|l|l|}
\hline Gloss & Senior & Base & Junior & Gloss \\
\hline MM & pakanowi & pak- & pakari & fDC \\
\hline FM & muthanowi & muth- & muthari & fSC \\
\hline MF & ngatyanowi & ngaty- & ngatyari & mDC \\
\hline FF & mayanowi & may- & mayarari ${ }^{10}$ & $\mathrm{mSC}$ \\
\hline
\end{tabular}

Source: Adapted from Taplin (1879).

Now the base of two of the grandkin terms of Table 14.3, plus the FeB term ngop-, are found additionally in affinal (in-law) terms, shown in Table 14.4. Two separate suffixes are involved, -antun and -eli. Meyer gives three forms in -antun. The only similar form in the other sources is Berndt and Berndt's mayanti, which looks like Meyer's mayantun without the - un but with the addition of the singular suffix $-i$. I therefore analyse the derivational suffix as just-ant. Mayareli, which contains the same extra -ar- as mayarari in Table 14.3, is attested from Taplin, Radcliffe-Brown and Berndt and Berndt. Ngopeli is attested from Radcliffe-Brown and Berndt and Berndt, who omit the final $-i$. Hence I treat the relevant suffix as just $-e l$. The function of the suffixes - ant and -el is not otherwise known. For our purposes, it is sufficient to treat the affinal terms as derivatives of the grandkin terms.

Table 14.4. Grandkin and affine terms.

\begin{tabular}{|l|l|l|l|l|l|}
\hline Gloss & Base & Junior -ar & In-law -ant & In-law -el & Gloss \\
\hline FF/mSC & may(ar)- & mayarari & mayant- & mayarel- & $\mathrm{HF} / \mathrm{mSW}$ \\
\hline FM/fSC & muth- & muthari & muthant- & - & {$[\mathrm{HM}] / \mathrm{fSW}$} \\
\hline FeB/myBC & ngop- & ngopari & ngopant- & ngopel- & $\mathrm{HB} / \mathrm{mBW}$ \\
\hline
\end{tabular}

Source: Adapted from Meyer (1843), Taplin (1879), Radcliffe-Brown (1918) and Berndt and Berndt (1993).

As for the meanings of the in-law terms, mayant-and mayarel-appear to be synonyms, although there is the possibility that they belong to different dialects. Berndt and Berndt give two senses for mayant-: the senior affine 'husband's father (or his brother)' as well as its junior reciprocal 'man's (or brother's) son's wife'. Meyer gives only the junior term 'daughter-in-law', which I interpret as $\mathrm{mSW}$ on the basis of the other

10 The form mayarari presents a difficulty in that it appears to have an extra syllable. But the expected mayar is attested in the forms spelled maiyar (Radcliffe-Brown 1918) and maiar and mair (Berndt and Berndt 1993). 
sources; the expected senior sense would be HF. For mayarel both Taplin and Radcliffe-Brown give both the senior and junior senses, while Berndt and Berndt give only the junior meaning 'man's or brother's son's wife'. For muthantun as well Meyer gives only the junior sense-in fact the same undifferentiated gloss 'daughter-in-law' as for mayantun; I assume that it must be interpreted as fSW, and probably had the reciprocal senior sense $\mathrm{HM}$ as well. For ngop(ano) vs ngopar-, the senses of FeB and its reciprocal yBC are assured from Taplin, Radcliffe-Brown and Berndt and Berndt, while Meyer gives simply 'uncle' vs 'nephew'. For ngopel both RadcliffeBrown and Berndt and Berndt provide glosses $\mathrm{HB}$ and its reciprocal mBW; for ngopantun Meyer gives an undifferentiated gloss 'sister-in-law', which I infer is mBW. The semantic relations between the grandkin terms and their affinal derivatives can be seen by comparing the first and last columns of Table 14.4 .

\subsection{Ngangaruku}

Radcliffe-Brown (1918: 243-46) discusses the kinship terms of what he called the 'Ngangaruku tribe', located further up the Murray River from the Ngarrindjeri, between Mannum and Herman's Landing, whose social organisation he found to be similar in the main to that of the Ngarrindjeri. ${ }^{11}$ Here two of the grandkin terms, paka and ngatta (in his spelling), appear to be cognate with Ngarrindjeri pak- and ngatyrespectively. The grandkin terms extend to the grandparent's siblings of both sexes (e.g. $M F=M F B / Z$ ) and the same applies to their reciprocal use $(\mathrm{mDC}=\mathrm{BDC})$. Radcliffe-Brown notes as an interesting feature the application of grandkin terms to refer to in-laws of the parents' and children's generations, discussing how this works only from a woman's viewpoint (his informant being a woman named Jenny).

A woman applies the term noidla to her father's mother and to the brothers and sisters of the latter, and also to her husband's mother and to her son's wife. Her son's children are also noidla ... A woman calls her husband's father metsa, that being the term she also applies to a father's father. She also calls the wife of her napnap (brother's son) metsa $^{12} \ldots$ (Radcliffe-Brown 1918: 245)

11 The language is apparently in a dialect relation with Ngayawung.

12 This is the reciprocal of HFZ; hence we can assume that the usage of these terms extends to siblings. It would be expected that metsa would also be used by HF for mSW. 
The resultant senses are set out in Table 14.5.

Table 14.5. Ngangaruku grandkin and affinal terms.

\begin{tabular}{|l|l|l|}
\hline Grandkin gloss & Form & Affinal gloss \\
\hline $\mathrm{MM}(\mathrm{Sb}), \mathrm{f} / \mathrm{ZDC}^{13}$ & paka & - \\
\hline $\mathrm{MF}(\mathrm{Sb}), \mathrm{m} / \mathrm{BDC}$ & ngatta & - \\
\hline $\mathrm{FM}(\mathrm{Sb}), \mathrm{f} / \mathrm{ZSC}$ & noidla & HM/fSW \\
\hline $\mathrm{FF}(\mathrm{Sb}), \mathrm{m} / \mathrm{BSC}$ & metsa & HF, $[\mathrm{HFZ}] /[\mathrm{mSW}], \mathrm{fBSW}$ \\
\hline
\end{tabular}

Source: Adapted from Radcliffe-Brown (1918).

\subsection{Summary of Lower Murray kin terms}

In both Ngangaruku and Ngarrindjeri it is only paternal grandkin terms that have been documented as being related to affinal terms, unlike Dharumba, where all four grandkin terms are involved. Note that in Ngangaruku the senior and junior terms are identical, whereas in the other languages one is usually a derivative of the other. In Ngarrindjeri the relationship between terms for parent's sibling and sibling-in-law seems to be a related phenomenon and deserving of a similar explanation. In an attempt at explanation Taplin (1879: 164) correctly noted that a man's daughter-in-law, mayarel- $\mathrm{mSW}$, is the mother of $\mathrm{mSC}$, the man's paternal grandchild, may-, reciprocal of FF. His further explanation in terms of patrilineal clan succession is too vague, as is Radcliffe-Brown's suggestion that the terminological equivalence represent traces of an earlier matrimoiety system.

\section{Cape York Peninsula}

\subsection{Wik Mungkan}

In some of the languages of western Cape York Peninsula we find similar phenomena. The anthropologist Donald Thomson did a considerable amount of work on kinship in the area in the 1930s. He described some patterns in the use of kin terms that provide the clue to our puzzle; I begin with his data on 'Wik Monkan' (Thomson 1972: 15-20). In Wik Mungkan, a Middle Paman language, only three grandparental terms are used: the same

13 To be read as: mother's mother or her siblings, and reciprocally the daughter's child of a female ego or of one's sister. 
terms is used for cross-grandparents MF and FM. The junior reciprocals involve a suffix $-i(n) y a y$; see Table 14.6. A more recent linguistic source, the Wik Mungkan dictionary (Kilham et al. 1986), gives the grandkin terms shown in Table 14.7. For the older generation the basic stems are compounded with wuut 'old man' and wayyow 'old woman'. Otherwise a suffix -(an) chin may occur, including when used for address.

Table 14.6. Wik Mungkan grandkin terms.

\begin{tabular}{|l|l|l|l|}
\hline Senior gloss & Senior form & Junior form & Junior gloss \\
\hline FF & pola & poliyan & $\mathrm{mSC}$ \\
\hline MM & kema & keminyan & fDC \\
\hline MF & yatja & natjiyay & $\mathrm{mDC}$ \\
\hline FM & natja & natjiyan & fSC \\
\hline
\end{tabular}

Source: Thomson (1972).

Table 14.7. Wik Mungkan grandkin terms.

\begin{tabular}{|c|c|c|c|c|}
\hline Senior gloss & Senior form & Senior address & Junior form & Junior gloss \\
\hline $\mathrm{FF}(\mathrm{B})$ & puulwuut & puulanchin & puuliyang & $\mathrm{mSC}$ \\
\hline $\mathrm{MM}(\mathrm{Z})$ & kemwayyow $^{14}$ & kemchin & kemiyang & fDC \\
\hline $\mathrm{MF}(\mathrm{B})$ & ngechwuut $^{15}$ & ngechanchin & ngechiyan & $\mathrm{mDC}$ \\
\hline $\mathrm{FM}(\mathrm{Z})$ & ngechwayyow & & ngechiyan & fSC \\
\hline
\end{tabular}

Source: Kilham et al. (1986).

In this society, the normal marriage is between classificatory crosscousins. A woman's preferred husband is the son of a (classificatory) kala MyB. A (prospective or actual) HF is distinguished as kal amp 'poison uncle' vs kal kampan, a 'friend-uncle, not for marrying'. But an alternative form of address - making reference to her children — is available.

A woman's kala [MyB] may be her father-in-law. If he is she calls him puk pol'nyin, child's pola [FF], and he calls her poliyan [reciprocal of FF] kallin, poliyan carrier, or mother of (my) poliyan. Similarly a woman calls her HM (her pinya [FeB]) puk yat'njin, child's yatja waiyo [FMZ] and she calls her SW kat'n yatjiyan, mother of (my) yatjiyan. (Thomson 1972: 20) ${ }^{16}$

14 A short form kem is also used.

15 An alternative form is athiy.

16 On the previous page Thomson says that the woman and her father-in-law 'may address' one another in these terms. So it seems there are two possibilities for addressing in-laws, both using consanguineal terms: one based on marriage practices and the other based on relations to a child. 
This naming practice — using the child as a reference point - is confirmed, at least for parents-in-law, from the Wik Mungkan dictionary. ${ }^{17}$ The kin term puulanchin $(\mathrm{FF})$ is:

used especially in phrases such as puk ngath puulanchin ${ }^{18}$ 'my children's grandfather on father's side' and as such is the term used by a woman to address her father-in-law. (Kilham et al. 1986: 195)

A similar statement is made concerning ngechanchin, a term of address for FM and MF: 'A common expression is also: puk ngathar ngechanchin ${ }^{19}$ "she's grandmother of my children"' (Kilham et al. 1986: 140). Although the dictionary does not give phrasal glosses for grandchildren, it goes beyond Thomson's data in providing analytical glosses of a similar type for siblings-in-law. Table 14.8 indicates the available terms for affinal relations. Husband's parents are referred to as 'my child's grandparent', spouse's senior sibling-in-law as 'my child's parent's elder sibling', and spouse's junior sibling-in-law in terms of the function of the in-law in relation to the child.

Table 14.8. Wik Mungkan in-law terms.

\begin{tabular}{|l|l|l|l|}
\hline Cons. gloss & Consanguineal & Affinal form & Affinal gloss \\
\hline FF & puulanchin & puk ngath puulanchin & $\mathrm{HF}$ \\
\hline FM & ngechanchin & puk ngathar ngechanchin & $\mathrm{HM}$ \\
\hline $\mathrm{FeB} / \mathrm{Z}$ & piny(chin) & puk ngath pinychin & $\mathrm{HeB} / \mathrm{Z}$ \\
\hline $\mathrm{MeB} / \mathrm{Z}$ & muk(anchin) & puk ngath mukanchin & $\mathrm{WeZ}$ \\
\hline $\mathrm{yZC}$ & mukayng & mukay-wunpan & $\mathrm{yZH}$ \\
\hline $\mathrm{FyB}$ & $?$ & puk ngath emathan $^{21}$ & $\mathrm{HyB}$ \\
\hline
\end{tabular}

Source: Kilham et al. (1986).

It becomes clear from the data of both Thomson (1972) and Kilham et al. (1986) that parents-in-law and siblings-in-law and their reciprocal relations may be described in terms of their relation to the child of the propositus. That is, the relationship is referenced from the viewpoint of the child: the propositus refers to their parent-in-law in terms of the child's grandparents, and, reciprocally, the senior affinal relatives refer to

17 There is an alternative strategy for describing parents-in-law as taboo or 'poison' uncles and aunties: kaal-aamp WF, piny-kench WM, the first member of the compounds being MyB and FZ respectively.

18 Literally, 'child-to.me FF-sEnior'.

19 Literally, 'child-to.me FM-sEnior'.

20 Literally, 'yZC begetter'.

21 Literally, 'my child raiser'. 
their daughter- or son-in-law in terms of their own grandchild. Likewise a person may refer to their brother- or-sister-in-law in terms of the child's relation to their parent's sibling, and reciprocally these refer to their in-laws as the parent of their nephew or niece.

\subsection{Other Cape York languages}

Similar derivation of affinal terms from terms for grandkin and uncles and aunts can be found in some Northern Paman languages. Thomson (1972: 21-24) presents data from Tjungundji and Hale (1965, 1997) from Linngithigh. Here phonological changes have somewhat obscured the etymological relations and the morphological details are not fully understood. Accordingly, and for reasons of space, I will refrain from presenting the full evidence here. Regarding forms, an example of the relations can be seen in Tjungundji thaya MF, thandhi (-ndhi is the junior suffix) $\mathrm{mDC}$ but also affinal $\mathrm{mDH}$, and thanuma thandhi $\mathrm{WF}$. In Tjungundji affinal terms are based on all four grandkin terms as well as on $\mathrm{FeB} / \mathrm{Z}$ and $\mathrm{FyB} / \mathrm{Z}$. (Wik Mungkan is the only language in my data that attests a terminological relation between MeSb and WeSb.) For Linngithigh Hale (1965) provides revealing glosses such as ngom inhaghay ' $\mathrm{HeB}$, his (i.e. woman's son's) FeB' in comparison to inhaghay FeB and ayom.thindhigh ' $\mathrm{mDH} / \mathrm{WF}$, to whose child I am thiy' vis-à-vis thiy MF. Such glosses emphasise the child-centred nature of the terms.

\section{Discussion}

\subsection{Teknocentricity}

We have now found a recurrent pattern of lexical relationships in three widely separated regions of Australia: the south-east coast, the lower Murray River, and Cape York Peninsula in the far north-east. In this pattern affinal kin are referred to in terms that reflect the consanguineal relation they bear to a child: my spouse's parents in terms of my child's grandparents and my spouse's siblings in terms of my child's uncle or aunt. Furthermore, since kin terms may be reciprocal, a person's son- or daughter-in-law is referred to in terms of being the parent of a (potential) grandchild. 
I propose to call this a 'teknocentric' usage of kin terms. The word teknocentric is derived from a classical Greek noun teknon meaning 'offspring', whether son or daughter, which is based on a root tek'bear', 'beget'. Note that this root refers to both maternal and paternal relations, which makes the term especially suitable for describing parentchild relations in Australian languages, since these typically distinguish terminologically between a woman's and a man's children. ${ }^{22}$

\subsection{Pragmatic explanation}

These equivalences are not simply a matter of semantic structure but require a pragmatic explanation. They involve a shift in propositus, the person from whose perspective the relationship is calculated. This is a kind of altercentric usage, as described by Merlan (1982: 127) for the Mangarrayi:

A senior speaker, in talking to a junior relative (especially a young child), tends to refer to third persons in terms of the junior's relationship to them. Thus MoMo addressing DaCh may say with reference to her own husband 'Where is (your) jabjab?' (speaker's husband, child's MoFa) using the altercentric referential mode.

Several kinds of motivations may be hypothesised for teknocentric usage. The most obvious is accommodation to children within a family context. Parents would refer to their own in-laws using the terms that their children use. This would apply especially in speech directed to a child (e.g. 'give it to grandma'). Then a mother may, especially in the presence of her child, address her own HM with a grandparental term, used almost as a name (e.g. 'here, take it grandma'). These habits may extend to using the grandparental term in more general contexts as well. Altercentric reference also serves an instructional purpose: 'children are constantly being taught how they should refer to others by being spoken to in terms of their relationship to them' (Merlan 1982: 129).

22 McConvell (2018: 249) has used a similar term, filiocentricity, based on Latin filius 'son' and filia 'daughter', for a narrower sense describing a 'pattern where the term used converges on the form used to and by the child in a parent-child dyad'. 
A second motivation may involve avoidance. Fêng (1937: 203) describes teknocentric usage as 'a circumlocutory way of expressing embarrassing relationships'. ${ }^{23}$ The use of consanguineal terms for affinal relatives thus constitutes a kind of euphemism. It serves to disguise reference to the marriage relationship with its sexual connotations (cf. Garde 2013: 121). Note that all the examples we have discussed involve the replacement of a spousal term: 'husband's or wife's father, mother, brother, sister' by 'father's or mother's father, mother, brother, sister' respectively; likewise, 'son's wife' by 'son's child's mother' and 'daughter's husband' by 'daughter's child's father' (although here the reference to the child may not be explicit).

Third, teknocentric reference to affines is one of a number of strategies employed in the etiquette of Australian societies to make indirect reference to individuals. It is becoming well known that Aboriginal people use many strategies other than the use of names to indicate who they are referring to. Some of this indirect referencing requires much inferencing on the part of hearers, as is amply illustrated in Garde (2013) and Blythe (2018).

\subsection{Implications for semantic description}

It is clear that the shared semantic content in teknocentrically related kin terms-especially where there is pure polysemy, as in Ngangaruku between noidla FM and HM-would be impossible to capture in a componential analysis, such as that illustrated for the Australian language Nyamal in Burling's (1970) chapter 'Kinship terminology', where all possible senses of a term are to be captured by a combination of features such as generation, sex, seniority, etc.

Scheffler's (1978) approach is more promising. He accounts for many of the multiple senses of individual Australian kin terms (i.e. polysemies) in terms of equivalence rules, stated as expansions or extensions of a primary sense along various parameters. Thus $\mathrm{F}$ is extended to $\mathrm{FB}$ and $\mathrm{M}$ to $\mathrm{MZ}$ by a 'same-sex sibling-merging rule'. Actually the direction of his merging rules is the opposite of extension: they involve rewriting a string of relations in terms of fewer symbols: for example FBS $\rightarrow$ FS (since FB = F) = B. Scheffler (1978: 145) has a 'spouse-equation rule' that relates affinal to consanguineal

23 Fêng uses the term 'teknonymic' to describe this usage in Chinese. But teknonymy is not the same thing as our teknocentricity: it is a term invented by E.B. Tylor 'to describe the custom whereby a person is called the father, mother, grandfather or grandmother, etc. of one of his descendants instead of by his own name' (Lévi-Strauss 1969: 348-49). For example, Anna may be referred to as 'Mary’s mother'. 
relationships: $\mathrm{Sp} \rightarrow$ Cousin, $\mathrm{SpM} \rightarrow \mathrm{FZ}, \mathrm{SpF} \rightarrow \mathrm{MB}$, etc. These relations result from marriage practices, such as intermarriage between kin who are terminologically first cross-cousins. Scheffler's equivalence formulas do not make direct reference to their motivation. Nor do any of them involve shifts of propositus of the kind we have seen here. One could however construct a rule for the equivalence $\mathrm{HF}=\mathrm{FF}$, which would substitute $\mathrm{fCF}$ for $\mathrm{H}$, thus $\mathrm{HF} \rightarrow \mathrm{fCFF}$, and for the reciprocal equivalence $\mathrm{mSW}=\mathrm{mSCM}$, one which replaces $\mathrm{W}$ with $\mathrm{mCM}$.

The Natural Semantic Metalanguage (NSM) approach championed by Anna Wierzbicka, could, it seems, account for the kinds of relations I have described here. Her approach to the explication of kin term meanings, as outlined in Wierzbicka (2017), is anchored in the child's perspective, pays attention to who is using the term and to whom, incorporates pragmatics and could apparently incorporate the shifts in propositus of the type described above. ${ }^{24}$

\subsection{Semantic change}

The reader will have noticed that our teknocentric terms involve different degrees of explicitness with respect to the altered propositus. An expression like Wik Mungkan puk ngath puulanchin 'my child's FF [= my HF]' is fully explicit. A term like Linngithigh ngom inhaghay 'his $\mathrm{FeB}[=\mathrm{my} \mathrm{HeB}]$ ' requires the hearer to infer that the perspective is the speaker's child. A form like Ngarrindjeri mayarel $\mathrm{mSW}$, presumably derived from $\mathrm{mSC}$, requires an inference concerning how the referent is related to the grandchild. Ngangaruku metsa FF, which is used without any modification in the sense HF, either requires a strong inference or has to be understood as a synonymous kin term. When the teknocentrically used term has become opaque-whether through the irrecoverability of the shifted propositus, the lack of transparency of the derivational morphology, or replacement of the term for the consanguineal relationsemantic change will have taken place. Even without these prerequisites, semantic change takes place when invited inferences are reanalysed as primary senses (Traugott and Dasher 2002).

24 I am not competent to attempt to supply NSM-style formulas explicating these kin terms. I would however welcome an NSM description of these phenomena. 


\subsection{Implications for etymology 25}

If the teknocentric usage of consanguineal kin terms to indicate affinal relations has been widely used and has resulted in semantic change, we can expect that more cognates between the two kinds of kin terms remain to be discovered. This applies both within and across languages. Within a given language, a form like Linngithigh ayom.londhigh $\mathrm{mSW}$ may no longer be synchronically perceived as being lexically related to olay FF. Interaction with other kinds of semantic extension may lead to some interesting cognate senses. For example, kami (or a reflex such as Wik Mungkan kem(a)) is MM in many Pama-Nyungan languages. Apparent derivatives are found in the sense of WM in languages that lack kami as MM: kamintha in Gathang and kamiyan in Wangaaybuwan. These are nevertheless plausible reflexes of an earlier *kami MM. Furthermore, there is often polysemy between WM and FZ in Australian languages. In Wangaaybuwan kamiyan has both meanings-possibly by extension from WM. In some languages (e.g. Duungidjawu), kami has only the FZ sense- the language having unrelated terms for both WM and MM. It would be hard to account for the apparent cognacy of terms for MM and FZ without a teknocentrically based shift of the kind we have found.

\section{Conclusions}

Indigenous Australian societies are characterised by a multiplicity of means of referring to one's relatives, including various strategies of indirection. One such strategy is to substitute consanguineal kin terms for affinal ones, especially given the sensitivity surrounding allusions to spousal relations. Although the actual use in interaction of kin terminology has not been studied in many societies, and although the recorded kin terminology for many societies is lacking in detail, there are indications among attested kin vocabularies that a teknocentric usage of kin terms has led in a number of languages to the lexicalisation of consanguineal kin terms or derivatives therefrom as affinal kin terms. Thus the communicative practices are revealed by a careful study of the vocabulary of kinship.

25 I should admit that my main interest in Australian kin terminology is etymological: establishing which terms are cognates and identifying their earlier form and meaning. 


\section{References}

Berndt, Ronald M. and Catherine H. Berndt (1977). The World of the First Australians. Sydney: Landsdowne Press.

Berndt, Ronald M. and Catherine H. Berndt (1993). A World that Was: The Yaraldi of the Murray River and the Lakes, South Australia. Melbourne: Melbourne University Press.

Besold, Jutta (2012). Language Recovery of the New South Wales South Coast Aboriginal Languages. Unpublished PhD dissertation, The Australian National University, Canberra.

Blythe, Joe (2018). Genesis of the Trinity: The convergent evolution of trirelational kinterms. In Patrick McConvell, Piers Kelly and Sebastien Lacrampe (eds), Skin, Kin and Clan: The Dynamics of Social Categories in Indigenous Australia. Canberra: ANU Press, 431-71. doi.org/10.22459/skc.04.2018.13.

Burling, Robbins (1970). Man's Many Voices: Language in its Cultural Context. New York: Holt, Rinehart and Winston.

Dousset, Laurent, Rachel Hendery, Claire Bowern, Harold Koch and Patrick McConvell (2010). Developing a database for Australian Indigenous kinship terminology: The AustKin project. Australian Aboriginal Studies 2010/1: 42-56.

Elkin, Adolphus P. (1964). The Australian Aborigines: How to Understand Them (4th edn). Sydney: Angus and Robertson.

Fêng, H.Y. (1937). The Chinese kinship system. Harvard Journal of Asiatic Studies 2 (2): 141-275.

Garde, Murray (2013). Culture, Interaction and Person Reference in an Australian Language: An Ethnography of Bininj Gunwok Communication (Culture and Language Use-Studies in Anthropological Linguistics 11). Amsterdam: John Benjamins. doi.org/10.1075/clu.11.

Hale, Kenneth (1965). Unpublished letter to R. Lauriston Sharp. Cornell University Archives.

Hale, Kenneth (1997). A Linngithigh vocabulary. In Darrell Tryon and Michael Walsh (eds), Boundary Rider: Essays in Honour of Geoffrey O'Grady (Pacific Linguistics C-136). Canberra: The Australian National University, 209-46. 
Kilham, Christine, Mabel Pamulkan, Jennifer Pootchemunka and Topsy Wolmby (compilers) (1986). Dictionary and Source Book of the Wik-Mungkan Language. Darwin: Summer Institute of Linguistics, Australian Aborigines Branch.

Lévi-Strauss, Claude (1969). The Elementary Structures of Kinship (rev. edn). Translated from the French by James Harle Bell, John Richard von Sturmer and Rodney Needham, editor. Boston: Beacon Press.

McConvell, Patrick (2018). Enhancing the kinship anthropology of Scheffler with diachronic linguistics and centricity. In Warren Shapiro (ed.), Focality and Extension in Kinship: Essays in Memory of Harold W. Scheffler. Canberra: ANU Press, 227-260. doi.org/10.22459/FEK.04.2018.

McConvell, Patrick and Helen Gardner (2016). The unwritten Kamilaroi and Kurnai: Unpublished kinship schedules collected by Fison and Howitt. In Peter K. Austin, Harold Koch and Jane Simpson (eds), Language, Land and Song: Studies in Honour of Luise Hercus. London: EL Publishing, 194-208. Available at: www.elpublishing.org/PID/2014.

Merlan, Francesca (1982). 'Egocentric' and 'Altercentric' usage of kin terms in Mangarayi. In Jeffrey Heath, Francesca Merlan and Alan Rumsey (eds), Languages of Kinship in Aboriginal Australia (Oceania Linguistic Monographs No. 24). Sydney: University of Sydney, 125-40.

Meyer, Heinrich August Edward (1843). Vocabulary of the Language Spoken by the Aborigines of the Southern and Eastern Portions of the Settled Districts of South Australia ... Preceded by a Grammar. Adelaide: James Allen.

Radcliffe-Brown. A.R. (1918). Notes on the social organization of Australian tribes: Part 1. Journal of the Royal Anthropological Institute of Great Britain and Ireland 48: 222-53. doi.org/10.2307/2843422.

Scheffler, Harold W. (1978). Australian Kin Classification (Cambridge Studies in Social Anthropology 23). Cambridge: Cambridge University Press. doi.org/ 10.1017/CBO9780511557590.

Taplin, George (1873). The Narrinyeri. Adelaide: Government Printer.

Taplin, George (1879). The Folklore, Manner, Customs, and Languages of the South Australian Aborigines. Adelaide: Government Printer.

Thomson, Donald (1972). Kinship and Behaviour in North Queensland. Edited by H.W. Scheffler. Canberra: Australian Institute of Aboriginal Studies. 
Traugott, Elizabeth C. and Richard B. Dasher (2002). Regularity in Semantic Change (Cambridge Studies in Linguistics 96). Cambridge: Cambridge University Press.

Wierzbicka, Anna (2013). Kinship and social cognition in Australian languages: Kayardild and Pitjantjatjara. Special Issue, 'Semantics and/in social cognition'. Australian Journal of Linguistics 33 (3): 302-21. doi.org/10.1080/07268602. 2013.846458.

Wierzbicka, Anna (2017). The meaning of kinship terms: A developmental and cross linguistic perspective. In Zhengdao Ye (ed.), The Semantics of Nouns. Oxford: Oxford University Press, 19-62. 
This text is taken from Meaning, Life and Culture: In conversation with Anna Wierzbicka, edited by Helen Bromhead and Zhengdao Ye, published 2020 by ANU Press, The Australian National University,

Canberra, Australia.

doi.org/10.22459/MLC.2020.14 